\title{
Two new species, Cyrtandra bungahijau and C. vittata, and notes on Cyrtandra (Gesneriaceae) from Yapen Island, Indonesia
}

\author{
H. J. Atkins ${ }^{1}$, C. D. Heatubun ${ }^{2,3,4}$, L. Galloway ${ }^{1}$ \& G. L. C. Bramley ${ }^{2,5}$
}

Summary. Two new species of Cyrtandra (Gesneriaceae) are described; one apparently endemic to Yapen Island, Tanah Papua, the other present in Tanah Papua and in Papua New Guinea: both species are described and illustrated, and preliminary conservation assessments given. Notes on the identity of other known collections of Cyrtandra from Yapen are provided.

Key Words. New Guinea, Papua New Guinea.

\section{Introduction}

Cyrtandra J.R.Forst. \& G.Forst. is a large genus of c. 800 species of herbs, shrubs, climbers, and small trees (Atkins et al. 2013). It is a predominantly Southeast Asian genus and is found from the Nicobar Islands in the Indian Ocean, throughout Malesia, in Taiwan and the southern Japanese islands, in northern Australia and east across Polynesia to Hawaii. It is recorded on the Asian continent only as far north as central Thailand. Its centres of diversity are New Guinea and Borneo (each with over 100 species) and the Philippines (with over 80 species) (Atkins et al. 2013). It is found in the rainforest, from sea level to over $3000 \mathrm{~m}$.

The New Guinean island of Yapen in the Indonesian province of Papua is located in Cenderawasih Bay. The island has been selected as an area for priority conservation by Conservation International (Supriatna 1999), a World Wildlife Fund ecoregion (WWF n.d.), and designated as a natural reserve by the Indonesian Ministry of Forestry in 1982 for its unique bird life (Beehler 2007) and limestone and ultramafic flora (Johns 1997). Although several endemic species have been recorded (Johns 1995; Hughes et al. 2015), there has been relatively little botanical exploration on Yapen (Conn 1994; Johns 1997; Frodin 2007; van Steenis Kruseman n.d.), and certainly no prior focus on Cyrtandra. In 1923, Schlechter published his 'Gesneriaceae Papuanae', which included a revision of Cyrtandra across the whole of New Guinea with 54 newly described species (Schlechter 1923). Prior to this, new species had been published in various accounts resulting from major expeditions to New
Guinea (Schumann \& Lauterbach 1901; Lauterbach 1910; Moore 1916). Clarke's monograph of Cyrtandra (Clarke 1883) across its distribution, only recognised five species and one variety from New Guinea. Schlechter (1923) divided 87 of the 96 Cyrtandra species he recognised into two subgenera and 14 sections, leaving nine unplaced, four of which were only noted as being new and not formally described. The subgenera were distinguished by corolla morphology; sections generally by combinations of characters. Species published from New Guinea since Schlechter (1923) have been from mountainous areas on the mainland (Burtt 1971; van Royen 1983).

To date, no Cyrtandra species have been specifically described from Yapen, and the island has not been listed in any species' distribution notes. We have only been able to source specimens that were collected in 1939 on an expedition by van Dijk, a Dutch Forest Officer, to Yapen (Jappen) and Biak islands (van Steenis Kruseman, n.d.). Frodin's detailed account of biological exploration of New Guinea in the 'Ecology of Papua' series (Frodin 2007), does list a number of earlier expeditions that went to Yapen, but many of these seem to have had a non-angiosperm focus (e.g. Crown Prince Leopold of Belgium, 1929 [only algae, lichen and mosses]; E.L.Cheeseman, 1938 - 39 [mainly entomology]), and after searching the collections at BM, E, K and L, we haven't found any further specimens (herbarium acronyms follow Thiers [continuously updated]).

\footnotetext{
Accepted for publication 22 May 2019. Published online 3 July 2019

1 Royal Botanic Garden Edinburgh, 20A Inverleith Row, Edinburgh, Scotland, EH3 5LR, UK.

2 Herbarium, Royal Botanic Gardens, Kew, Richmond, Surrey, TW9 3AE, UK.

3 Badan Penelitian dan Pengembangan Daerah Provinsi Papua Barat, Jl. Brig. Jend. Mar. (Purn.) Abraham O. Atururi, Arfai, Manokwari, Papua Barat 98314, Indonesia.

4 Fakultas Kehutanan, Universitas Papua, Jl. Gunung Salju, Amban, Manokwari, Papua Barat 98314, Indonesia.

5 Corresponding author e-mail: g.bramley@kew.org
} 
Joint fieldwork between staff of the Royal Botanic Garden Edinburgh and Universitas Papua in 2009 resulted in the acquisition of two living collections of Cyrtandra. It has not been possible to match these plants with any known species or any of the Yapen Cyrtandra specimens that we have located. Here we present a description and illustration of the two new species, C. bungahijau Bramley \& H.J.Atkins and C. vittata Bramley \& H.J.Atkins, as well as notes on the other Yapen collections known to us.

\section{Materials and Methods}

All available type specimens of New Guinea Cyrtandra (held at B (online), BM, E, K, L (online), P (online)) were examined to establish the identity or novelty of the collections from Yapen Island. The descriptions were based on living material in cultivation at the Royal Botanic Garden Edinburgh (RBGE), photographs of plants growing in the field, and herbarium and spirit material. All cited specimens have been seen by the authors.

The proposal for IUCN conservation categories was made following the IUCN Red List Categories and Criteria and associated guidelines (IUCN 2012).

\section{Taxonomic Treatment}

Cyrtandra bungahijau Bramley $\mathcal{E}$ H.J.Atkins sp. nov. Type: Indonesia, Tanah Papua, Yapen Island, Kosiwo, Ambaidiru, Kapit Atusamban behind the homestay in Ambaidiru Village, $1000 \mathrm{~m}$, cuttings collected 18 Feb. 2009, Argent et al. ABEG 218, cultivated at RBGE as 20090826, vouchered as Atkins 57 (holotype E!; isotype MAN!).

http://www.ipni.org/urn:lsid:ipni.org:names:77197082-1

Stocky shrub to $75 \mathrm{~cm}$. Stems thick, tessellate, corky, glabrous. Leaves opposite; those of a pair subequal or with one significantly larger than the other but both well developed; petioles c. $5 \mathrm{~mm}$, somewhat corky, tessellate, glabrous; blades $7-15(-30) \times 4$ $-7(-15) \mathrm{cm}$, elliptic, thick, leathery, apex short acuminate, acumen $2-3 \mathrm{~mm}$, base decurrent, margin distantly serrulate to almost entire; $7-8$ pairs of lateral veins, tertiary venation reticulate, sparse and feint on upper surface, obscure below, upper surface of mature leaves mid green with a covering of coarse white hairs, lower surface light green, sparsely hairy, more densely so on midrib and veins. Inflorescence subsessile, axillary, 1 - 2flowered. Bracts green, triangular, c. $7.5 \times 5 \mathrm{~mm}$, glabrous internally, externally with a fringe of coarse white hairs along the midvein and apically. Calyx green, tubular, c. $13 \mathrm{~mm}$ long, five-lobed but appearing three-lobed at apex, lobes c. $4 \mathrm{~mm}$ long, acute at apex, with coarse, white hairs externally. Corolla light green, narrow tubular, $25 \mathrm{~mm}$ long, glabrous towards base whilst inside calyx, becoming densely white hairy externally in the upper half, lobes extending forward, not spreading or recurved, mouth of corolla barely open, lobes oblong, somewhat acute at apex, upper lobes c. $3 \times 2$ $\mathrm{mm}$, lower lobes c. $2 \times 3 \mathrm{~mm}$, internally with a dense covering of glandular hairs in upper half of tube and on the lower lobes and with two very small outgrowths at the point of insertion of the filaments. Filaments white, straight, glabrous, c. $5 \mathrm{~mm}$ long, borne c. $15 \mathrm{~mm}$ from base of corolla. Anthers white, c. $2 \mathrm{~mm}$ long, thecae slightly divaricate, glabrous, with a short connective at the tips. Lateral staminodes c. $1 \mathrm{~mm}$ long, central staminode c. $0.5 \mathrm{~mm}$. Gynoecium c. $22 \mathrm{~mm}$ long overall; disk cupular with undulate margin, slightly lower on one side, c. $1.5 \mathrm{~mm}$, glabrous; ovary glabrous; style sparsely glandular hairy; stigma bilobed, lobes c. $1.5 \mathrm{~mm}$ long, pressed together on specimens seen. Fruit not seen. Figs $1 \& 2$.

RECOGNITION. Cyrtandra bungahijau Bramley \& H.J.Atkins is most similar to C. jadunae Schltr., in section Pachycyrtandra Schltr., but can be distinguished from it by its leaf bases (decurrent vs cuneate), calyx lobes ( $4 \mathrm{~mm}$ vs $12 \mathrm{~mm}$ ) and internal corolla indumentum (glandular hairy vs glabrous).

DISTRIBUTION. Indonesia: Papua, Yapen Island. See Map 1.

SPECIMENS EXAMINED. INDONESIA. Tanah Papua, Yapen Island, Kosiwo, Ambaidiru, Kapit Atusamban behind the homestay in Ambaidiru Village, 1000 m, cuttings collected 18 Feb. 2009, Argent et al. ABEG 218, cultivated as 20090826, vouchered as Atkins 57 (E, MAN).

HABITAT. Disturbed secondary forest; alt. $1000 \mathrm{~m}$. CONSERVATION STATUS. Due to the lack of collecting activity on Yapen or detailed information about threat, a conservation category of Data Deficient (DD) is proposed for this species and we emphasise the need for further survey work in this area.

ETYMOLOGY. This species is named for its distinctive green corolla; bunga hijau means 'green flowers' in Bahasa Indonesia.

NOTES. This species falls within Schlechter's subgenus Cyrtandra, section Pachycyrtandra. The subgenus contains those species that do not have strongly zygomorphic corollas and the section contains species with single or paired, large, densely hairy flowers and subequal well-developed leaves. The fruit of this new 


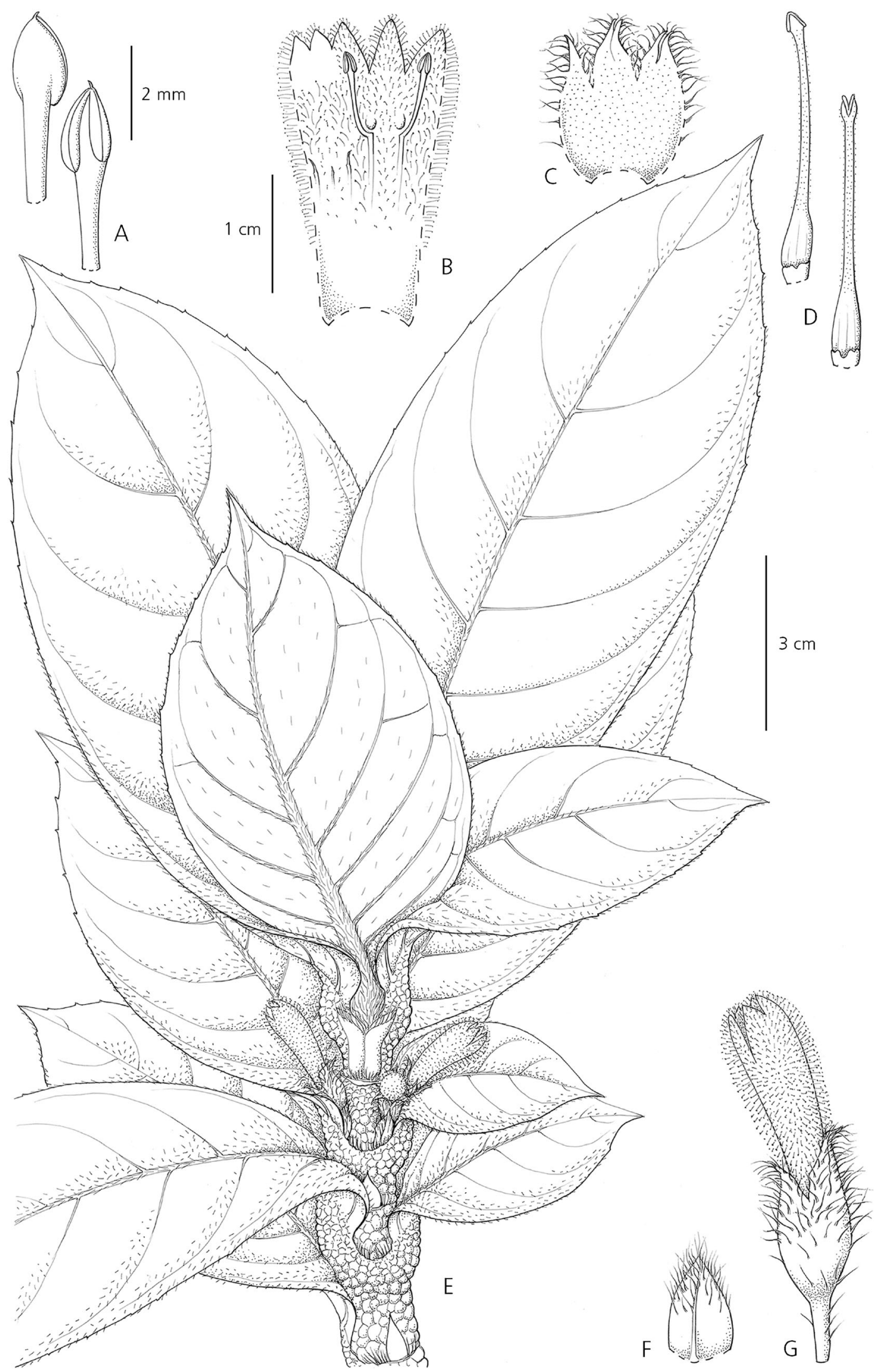

Fig. 1. Cyrtandra bungahijau. A anthers; B corolla, longitudinal section; C calyx, longitudinal section; D gynoecium; E habit; F bract; G flower, lateral view. From Atkins 57 (E). DRAWN BY CLAIRE BANKS. 

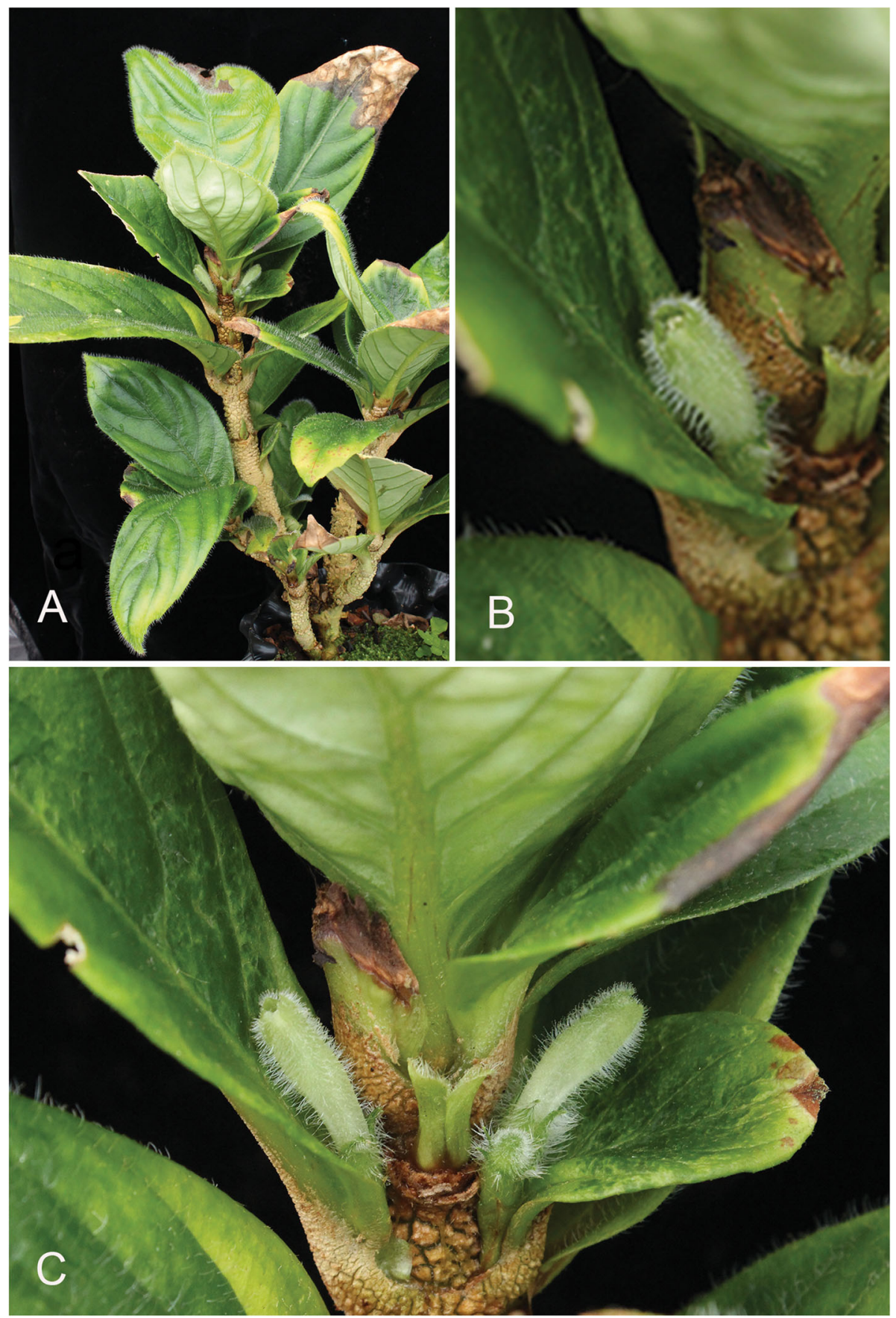

Fig. 2. Cyrtandra bungahijau. A habit; B \& C flowers in leaf axils. (RBGE20090826 vouchered as Atkins 57) PHOTOS: SADIE BARBER.

species has not been seen but others in this section have persistent calyces in fruit. Within the section, this new species is most similar to C. jadunae Schltr. from 'Jaduna' on the Waria River in Morobe Province, Papua New Guinea. Although the type of C. jadunae (Schlechter 19331) has not been found, comparison with Schlechter's description shows that the two species share glabrous ovaries and stamens that do not exceed the corolla but differ in the leaf bases (decurrent vs cuneate), the more deeply divided calyx in C. jadunae, and variation in indumentum inside the corolla (glabrous in C. jadunae and glandular hairy in C. bungahijau).

Cyrtandra vittata Bramley $\mathcal{E}$ H.J.Atkins sp. nov. Type: Papua New Guinea, Huon Peninsula, Cromwell Mts, 22 Oct. 2006, de Kok 1156 (holotype K!, isotype LAE!).

http:/ /www.ipni.org/urn:lsid:ipni.org:names:60478760-2 


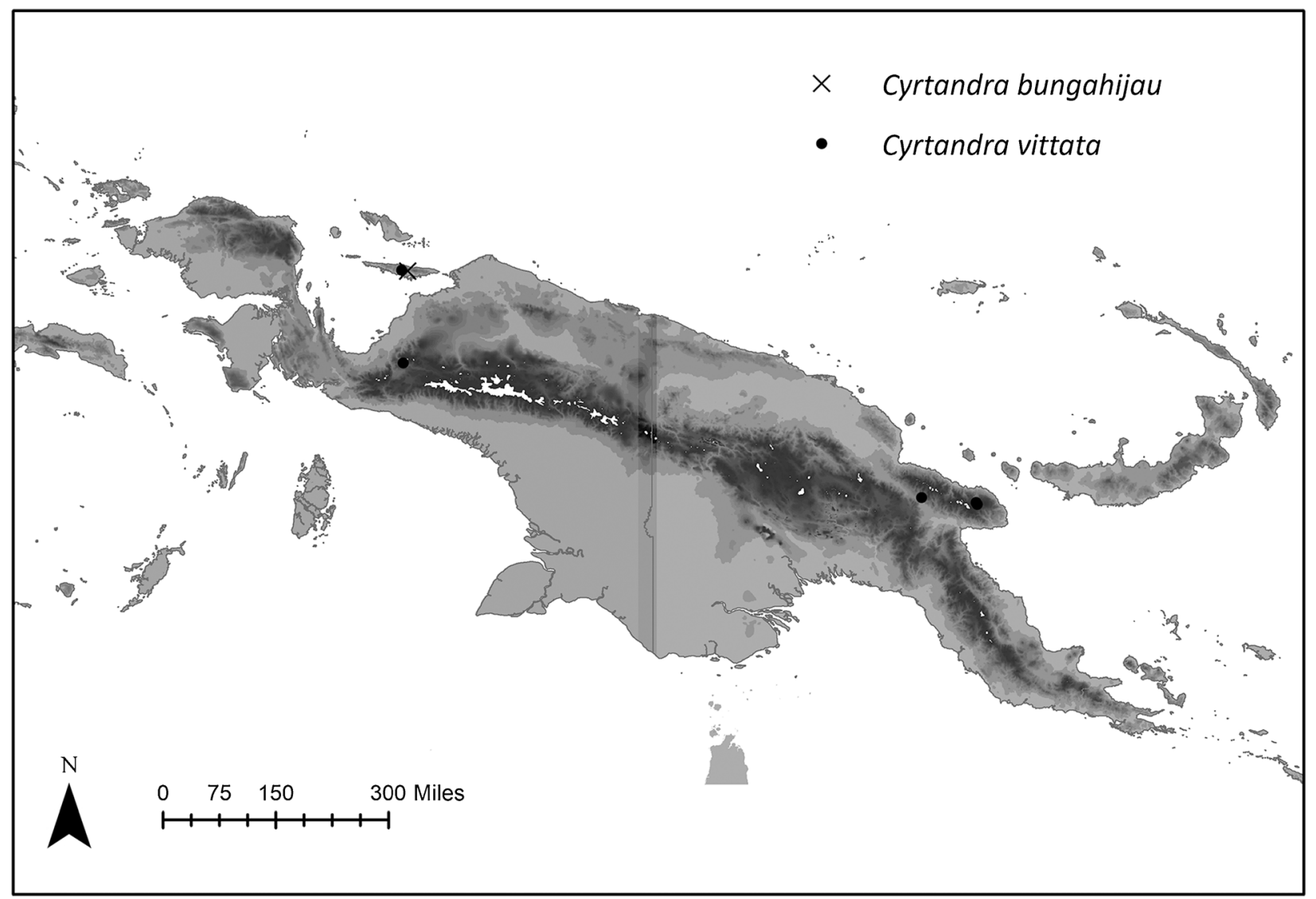

Map 1. Known distribution of Cyrtandra bungahijau and C. vittata.

Sparingly branched shrub to $1 \mathrm{~m}$. Stems woody at base, striate, glabrate, sparsely hairy on young growth. Leaves opposite, those of a pair subequal to strongly anisophyllous; petioles of major leaf 9 $20 \mathrm{~mm}$, hairy elliptic to slightly obovate; blades of subequal leaves and major leaf in anisophyllous pairs $(7-) 9-15(-21) \times(2-) 3.5-5.5(-6.4)$ $\mathrm{cm}$, apex long acuminate, up to $20 \mathrm{~mm}$, base cuneate, not decurrent, slightly asymmetrical, margin distantly serrate, the serrations often irregular; $5-8(-10)$ pairs of lateral veins, tertiary venation reticulate, sparse, upper surface of leaves mid green, slightly mottled, sparsely hairy, lower surface light green, sparsely hairy, more densely so on midrib and veins; petiole of minor leaf c. $5 \mathrm{~mm}$ or leaf sessile; blades elliptic, $1.8 \times 0.5 \mathrm{~cm}$ to stipulelike, $0.55-1 \mathrm{~cm}$ long. Inflorescence sessile, in leaf axils or where leaves have fallen, 1- 6-flowered, fasciculate. Bracts linear, c. $2 \mathrm{~mm}$ long, hairy, light green, tinged red. Pedicel light green, tinged red, $9-10$ $\mathrm{mm}$, hairy. Calyx dull red, tinged slightly green at apex and along central rib of each lobe, (8-) $10-12 \mathrm{~mm}$ long, hairy externally, evenly 5-lobed or upper three lobes slightly closer together than to the lower two, lobes $5-7 \mathrm{~mm}$, narrow acuminate. Corolla cerise pink with white longitudinal stripes running along the length of the corolla from the tip of the lobes to the base, funnelshaped, arcuate, held upright, somewhat laterally flattened, $27-30 \mathrm{~mm}$ long, with a covering of short, white eglandular hairs externally, lobes recurved, triangular, upper lobes $1.5-2 \times$ c. $3 \mathrm{~mm}$, lateral lobes $6-8 \times$ c. $4 \mathrm{~mm}$ and lower lobe $5-7 \times$ c. $5 \mathrm{~mm}$, inside of lobes densely glandular hairy. Filaments white, straight, 15 - $18 \mathrm{~mm}$ long, borne c. $10 \mathrm{~mm}$ from base of corolla, sparsely glandular hairy towards the apex. Anthers white, c. $2 \mathrm{~mm}$ long, cohering at tips before dehiscence, thecae parallel. Lateral staminodes c. $6 \mathrm{~mm}$, central staminode c. $2 \mathrm{~mm}$. Gynoecium 22 - $30 \mathrm{~mm}$ long overall; disk cupular but much lower on one side, with undulate margin, glabrous, c. $2 \mathrm{~mm}$; ovary more or less glabrous or with some tiny hairs and a few scattered glands; style densely glandular hairy particularly towards apex; stigma bilobed, flattening out when mature and appearing almost peltate, c. $1 \mathrm{~mm}$ across, white. Fruit green when young, turning white with age, cylindrical, c. $20 \times 4 \mathrm{~mm}$ when dried, 


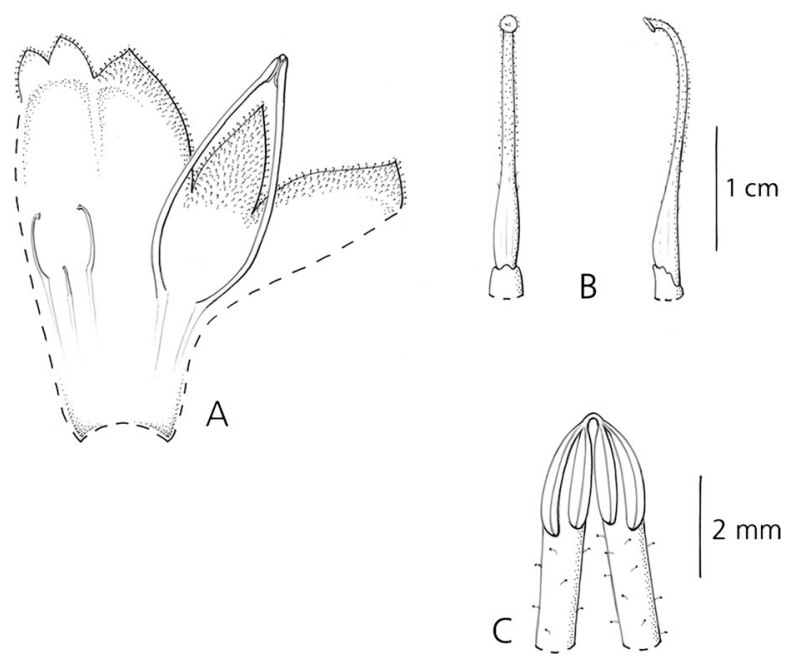

Fig. 3. Cyrtandra vittata. A corolla, longitudinal section; B gynoecium; C anthers. From Atkins 14 (E). DRAWN BY CLAIRE BANKS.

smooth and glabrous, calyx and base of style not persistent. Seeds small, numerous. Figs 3 \& 4.

RECOGNITION. Cyrtandra vittata Bramley \& H.J.Atkins is most similar to C. minjemensis Schltr., in section Loxanthe Schltr., but can be distinguished by its striped pink and white corolla (vs purple corolla) and caducous calyx (vs persistent calyx).

DISTRIBUtION. Indonesia: Papua; Papua New Guinea: Morobe. See Map 1.

SPECIMENS EXAMINED. PAPUA NEW GUINEA. Morobe: Huon Peninsula, Cromwell Mts, 22 Oct. 2006, de Kok 1156 (K, LAE); Indagen, 30 Oct. 2006, de Kok 1263 (E, K, LAE); Umi R., Markham Valley, 26 Nov. 1959, Brass 32708 (E, K). INDONESIA. Tanah Papua: Wissel Lake Region [Paniai Lakes], Djembodini-Kerimamba, 27 Feb. 1939, Eyma 4634 (K, L); Yapen Island, Kosiwo, Ambaidiru, Kapit Atusamban, 893 m, 19 Feb. 2009, Argent et al. ABEG 227, cultivated at RBGE as 20090734, vouchered as Atkins 14 (E, MAN).

HABITAT. Primary forest, often with some degree of disturbance; alt. $480-2000 \mathrm{~m}$

CONSERVATION STATUS. The unusual distribution pattern of this species gives a preliminary conservation assessment, using GEOCAT (Bachman et al. 2011), of LC (Least Concern) based on EOO, and EN (Endangered) based on AOO using a cell width of $2 \mathrm{~km}$. We suggest that, given the lack of collecting activity across the centre of this distribution (Gideon 2015), and the consequent likely underestimation of extent, that this species is listed as Least Concern.
ETYMOLOGY. This species is named for the distinctive vertical stripes on the corolla.

NOTES. This species falls within Schlechter's subgenus Glossophorae due to its strongly zygomorphic corolla. Within the subgenus, it can be tentatively placed in his section Loxanthe due to its mostly anisophyllous leaf arrangement, short brown indumentum, glabrous ovary, lack of outgrowth in the corolla tube and deeply divided calyx lobes. Species within this section should, however, also retain their calyx in fruit. We have only seen fruit on the cultivated plant, and in this case, the calyx is clearly caducous.

Within this section, Cyrtandra vittata most closely resembles C. minjemensis. We located two isotypes of this species (BO, P) but, unfortunately, both were sterile. We obtained permission from the Curator responsible for destructive sampling at $\mathrm{P}$, Dr Myriam Gaudeul, for material from the type for DNA extraction to confirm if the type of $C$. minjemensis was definitely distinct from the new material but we were, unfortunately, not successful in obtaining DNA. Despite an absence of molecular confirmation, sufficient differences with the original description of $C$. minjemensis including corolla colour (purple vs pink and white striped) and calyx persistence in fruit persuaded us that this should best be described as a distinct taxon.

The distribution of Cyrtandra vittata (see Map 1) is unusual both in its extent and also the marked disjunction between Tanah Papua and Morobe. From our initial taxonomic work, it appears that the distributions of some Cyrtandra species in New Guinea are wider than we have found to be typical in other areas of Malesia. From the literature, and discussions with colleagues, we have found examples of species that are distributed along the northern coast of New Guinea, some continuously, such as Medusanthera laxiflora (Miers) R.A.Howard (Utteridge 2011), and others patchily such as Actinodaphne multiflora Benth. and Schefflera waterhousiae Harms. (both D. Frodin, pers. comm.). These species are all likely to be dispersed by frugivorous birds: the patchy distributions could be due to lack of botanical collections across the area (Gideon 2015), or to the route of the dispersers. Perhaps the apparent distribution of $C$. vittata is a reflection of lower collecting density in western Papua New Guinea and eastern Tanah Papua, and further fieldwork would result in more records of it being found. As for the dispersal of $C$. vittata, we have no observations, but could speculate that the fleshy white fruit is dispersed by columbiform birds, as has been suggested for dispersal of Cyrtandra species across the Pacific to the Hawaiian archipelago (Cronk et al. 2005). 

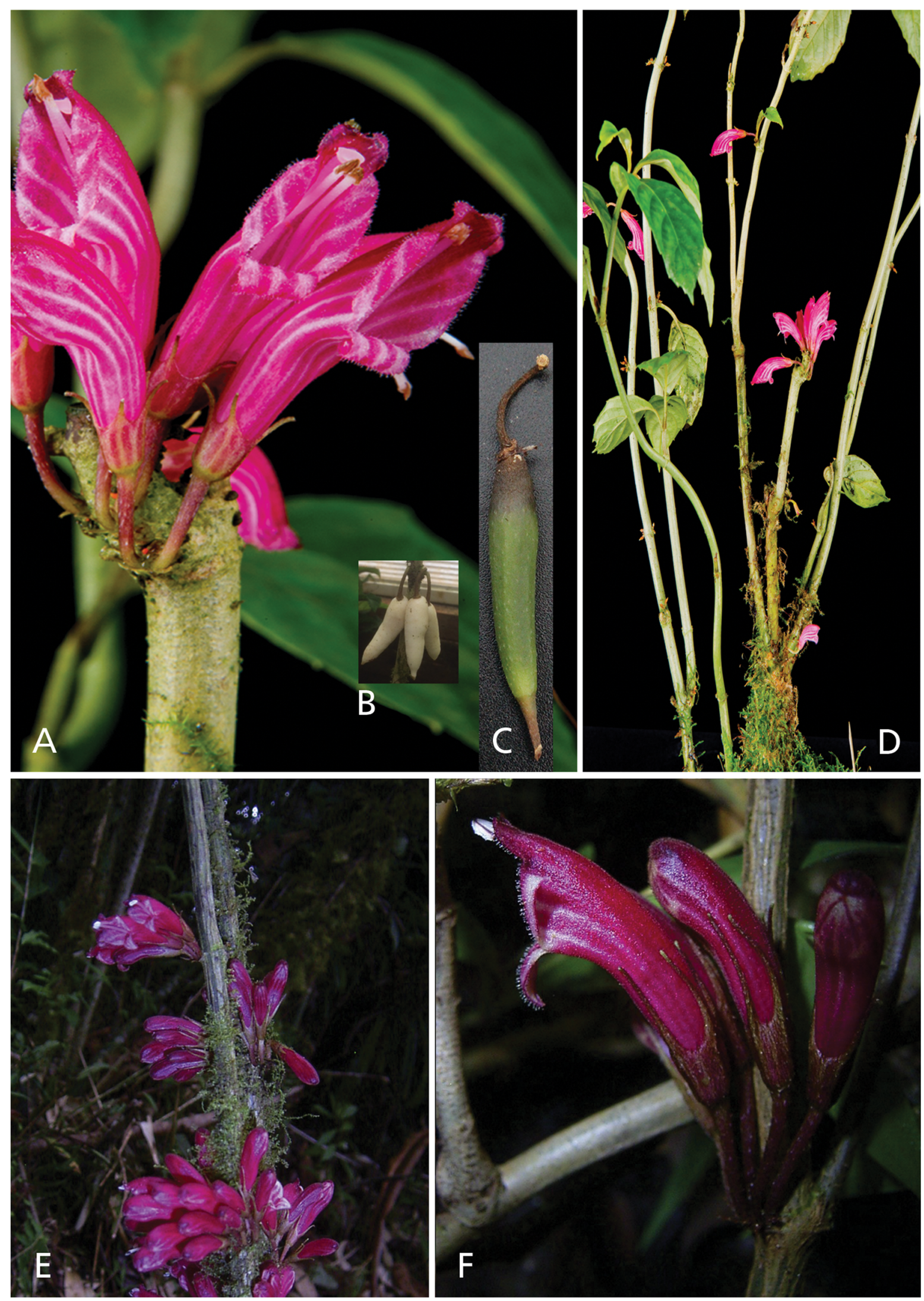

Fig. 4. Cyrtandra vittata. A inflorescence; $B$ mature fruits; $C$ immature fruit; $D$ habit; $E$ inflorescences; $F$ flower, lateral view. A - D (RBGE20090734 vouchered as Atkins 14); E - F de Kok 1156. PHOTOS: A, D LYNSEY WILSON; B, C HANNAH ATKINS; E, F ROGIER DE KOK. 
The collections from both extremes of this distribution are morphologically very similar and Atkins 14, from Yapen, and de Kok 1156 and de Kok 1263 from Morobe resolve as sister in an as yet unpublished phylogeny of Cyrtandra.

Two additional collections, Takeuchi 8618, also from Morobe, and Takeuchi 11289, from Chimbu Province in the Highlands Region, are similar in having pink/red and white striped corollas and are possibly closely related but have larger, more leathery leaves and larger flowers. The corolla is significantly longer, up to $40 \mathrm{~mm}$ long, with filaments that far exceed the mouth of the corolla at maturity, and the nectary disk is not distinctively lower on one side.

\section{Notes on other Yapen collections}

One of the authors (GLCB) is in the process of revising Papuan Cyrtandras. The notes that follow represent our preliminary attempts to identify the other collections known to us from Yapen, and to assign them to the sections described by Schlechter (1923). Until more detailed taxonomic research is completed, using Schlechter's work is the most practical method of specimen identification. We aim to establish whether Schlechter's sections represent monophyletic groups through future phylogenetic studies.

\section{Cyrtandra decurrens var. puncticulata C.B.Clarke}

Not assigned to section

SPECIMENS EXAMINED: Indonesia, Papua, Pulau Yapen: Aet Ẽ Idjan 153 (L).

\section{Cyrtandra janowskyi Schltr.}

Subgen. Cyrtandra; sect. Leucocyrtandra Schltr.

SPECIMENS EXAMINED: Indonesia, Papua, Pulau Yapen: Aet $\mathcal{E}^{2}$ Idjan 698 (L).

\section{Cyrtandra suberosa Schltr.}

Subgen. Glossophorae; sect. Centrosiphon Schltr.

SPECIMENS EXAMINED: Indonesia, Papua, Pulau Yapen: Aet Ẽ Idjan 201 (K, L).

\section{Cyrtandra sp. indet.}

Subgen. Cyrtandra; sect. Axillanthe Schltr.
SPECIMENS EXAMINED: Indonesia, Papua, Pulau Yapen: Aet $\mathcal{E}$ Idjan 82; 232 (both at L).

\section{Cyrtandra sp. indet.}

Not assigned to section

SPECIMENS EXAMINED: Indonesia, Papua, Pulau Yapen: Aet Eं Idjan 460 (L).

6. Cyrtandra sp. indet.

Not assigned to section

SPECIMENS EXAMINED: Indonesia, Papua, Pulau Yapen: Argent et al. ABEG 205 (E).

\section{Acknowledgements}

We thank the curators of the herbaria cited above for access to or loan of material, and Dr Myriam Gaudeul (P) for providing material for DNA extraction from the isotype of Cyrtandra minjemensis; Claire Banks for the detailed illustrations; Sadie Barber, Lynsey Wilson and Rogier de Kok for permission to use their photographs, and Nathan Kelso and Sadie Barber for excellent care of the living collections. GLCB is grateful to Tim Utteridge and David Frodin for informative discussions on species distributions in northern New Guinea. The new taxon was collected on Yapen Island during the Papua expedition of the Royal Botanic Garden Edinburgh in 2009, in which LG and CDH were involved. LG and CDH would like to thank Kementerian Riset dan Teknologi Republik Indonesia, Lembaga Ilmu Pengetahuan Indonesia, Universitas Papua, Kebun Raya Cibodas, Balai Penelitian Kehutanan Manokwari, BKSDA Papua I Sub Seksi Pulau Yapen, authorities in Serui, people and chief of Ambaidiru village, Pak Makarius, George Argent, Andrew Ensoll, Sadie Barber and Herkilaus Rumaikewi. Financial support for the expedition was provided by the Royal Horticultural Society, the Merlin Trust, Royal Botanic Garden Edinburgh Members' Committee, Royal Botanic Garden (Sibbald) Trust and the James \& Eve Bennett Charitable Trust.

Open Access This article is distributed under the terms of the Creative Commons Attribution 4.0 International License (http://creativecommons.org/ licenses/by/4.0/), which permits unrestricted use, distribution, and reproduction in any medium, provided you give appropriate credit to the original author(s) and the source, provide a link to the Creative Commons license, and indicate if changes were made. 


\section{References}

Atkins, H. J., Bramley, G. L. C. \& Clark, J. R. (2013). Current knowledge and future directions in the taxonomy of Cyrtandra (Gesneriaceae), with a new estimate of species number. Selbyana 31(2): 157 165.

Bachman, S., Moat, J., Hill, A. W., de la Torre, J. \& Scott, B. (2011). Supporting Red List threat assessments with GeoCAT: geospatial conservation assessment tool. ZooKeys 126: 117 - 126.

Beehler, B. M. (2007). Papuan terrestrial biogeography, with special reference to birds. In: A. J. Marshall \& B. M. Beehler (eds), The Ecology of Papua, Part One. The Ecology of Indonesia Series, Vol. VI: 196 - 206. Periplus Editions Ltd., Singapore.

Burtt, B. L. (1971). Studies in the Gesneriaceae of the Old World XXXIV. Notes Roy. Bot. Gard. Edinburgh 31: 35-52.

Clarke, C. B. (1883). Cyrtandreae. In: A. De Candolle \& C. De Candolle (eds), Monographiae Phanerogamarum, pp. 1 - 303. G. Masson, Paris.

Conn, B. J. (1994). Documentation of the Flora of New Guinea. In: C. L. Peng \& C. H. Chou, (eds), Biodiversity and Terrestrial Ecosystem. Academia sinica Monograph 14: 123 - 156. Institute of Botany, Taipei.

Cronk, Q. C. B., Kiehn, M., Wagner, W. L. \& Smith, J. F. (2005). Evolution of Cyrtandra (Gesneriaceae) in the Pacific Ocean: the origin of a supertramp clade. Amer. J. Bot. 92: 1017 - 1024.

Frodin, D. (2007). Biological exploration of New Guinea. In: A. J. Marshall \& B. M. Beehler (eds), The Ecology of Papua, Part One. The Ecology of Indonesia Series, Vol. VI: 14 - 107. Periplus Editions Ltd., Singapore.

Gideon, O. (2015). The flora of New Guinea: its origins, affinities and patterns of diversity and endemism. In: P. Shearman \& B. Mackey (eds), The State of the Forests of Papua New Guinea 2014: Measuring Change over the period $2002-2014$, pp. $115-135$. University of Papua New Guinea, Port Moresby.

Hughes, M., Barber, S., Heatubun, C. D. \& Gagul, J. (2015). Begonia yapenensis (Sect. Symbegonia, Begoniaceae), a new species from Papua, Indonesia. Eur. J. Taxon. 119: 1 - 6. https://doi.org/10.5852/ejt.2015.119.
IUCN (2012). IUCN Red List Categories and Criteria: Version 3.1. IUCN, Gland and Cambridge.

Johns, R. J. (1995). Biodiversity in Irian Jaya: Proposal for the listing of selected areas for priority conservation. Royal Botanic Gardens, Kew.

(1997). Background papers for the study of the flora and vegetation of the N.E. Kepala Burung, Irian Jaya, Indonesia. Royal Botanic Gardens, Kew.

Lauterbach, C. (1910). Gesneriaceae in resultats de Expedition Scientifique Neerlandaise a la Nouvelle Guinee en 1907 sous les auspices du Dr H. A. Lorentz. Nova Guinea 8: 325 - 332.

Moore, S. (1916). Gesneriaceae. In: H. N. Ridley, On plants collected in New Guinea, Report on the botany of the Wollaston Expedition to Dutch New Guinea. Trans. Linn. Soc. London 9: 1 - 284.

van Royen, P. (1983). Alpine Flora of New Guinea. Vol. 4. A. R. Gantner, Verlag, K. G., Vaduz.

van Steenis Kruseman, M. J. (n.d.) Cyclopaedia of Malesian Collectors. Available at:http:/ / www.nationaalherbarium.nl/ FMCollectors/. Accessed 1 Jan. 2018.

Schlechter, R. (1923). Gesneriaceae Papuanae. Cyrtandra. Beitr. Fl. Papuas. 10. Bot. Jahrb. Syst. 58: $244-495$.

Schumann, K. \& Lauterbach, K. (1901). Die Flora der Deutschen Schutzgebiete in der Sudsee. Gebruder Borntraeger Verlagsbuchhandlung. Leipzig.

Supriatna, J. (1999). The Irian Jaya biodiversity conservation priority-setting workshop. Final report. Conservation International, Washington D.C.

Thiers, B. [continuously updated]. Index Herbariorum: A global directory of public herbaria and associated staff. New York Botanical Garden's Virtual Herbarium. http://sweetgum.nybg.org/science/ih/.

Utteridge, T. M. A. (2011). A revision of the genus Medusanthera (Stemonuraceae, Icacinaceae s.l.). Kew Bull. 66: 49 - 81.

WWF (n.d.). Southeastern Asia: Island of Yapen in Indonesia. Available at: https:/ /www.worldwildlife.org/ ecoregions/aa0108. Accessed 1 Nov. 2017.

\section{Publisher's Note}

Springer Nature remains neutral with regard to jurisdictional claims in published maps and institutional affiliations. 